\title{
Report of Alternaria alternata causing leaf spot on Gerbera jamesonii in Brazil
}

\author{
Cristiano Bellé ${ }^{1}$ (B) $\cdot$ Marcia Gabriel $^{2} \cdot$ Ricardo Rubin Balardin $^{1} \cdot$ Daiane Dalla Nora $^{1} \cdot$ Zaida Inês Antoniolli $^{1}$
}

Received: 20 November 2018 / Accepted: 19 February 2019 / Published online: 4 March 2019

(C) Società Italiana di Patologia Vegetale (S.I.Pa.V.) 2019

Keywords Alternaria alternata $\cdot$ Leaf spot $\cdot$ Occurrence $\cdot$ Barberton daisy $\cdot$ Brazil

Gerbera jamesonii (family Asteraceae) is a popular perennial ornamental cut flower and potted plant with considerable economic importance. In April 2018, symptoms of leaf spots were observed on $G$. jamesonii 'Comum' in commercial fields of cut flower in Frederico Westphalen, Rio Grande do Sul state, Brazil. The symptoms of the disease on the leaves were characterized by the development of black, small, scattered dots, which gradually enlarged and coalesced to form large, oval, circular or irregular, black lesions. Leaf lesion samples were surface sterilized and placed on potato dextrose agar. Colonies were round, comprising a cottony mycelium of dark olivaceous hyphae. Conidiophores were septate, light-to-olive golden brown with a conidial scar from which conidia were produced. Conidia $(n=50)$ were obclavate to obpyriform, golden brown, with a cylindrical or coniform beak at the tip, and measured 26.3 to $60.2 \mu \mathrm{m} \times 12.1$ to $18.1 \mu \mathrm{m}$ with 2 to 5 transverse and 1 to 3 longitudinal septa. To further confirm the identification, molecular characterization was performed through the amplification and sequencing of the ITS, GAPDH, RPB2, TEF- $1 \alpha$ gene regions, using the primers and method described by Woudenberg et al. (2013). Sequences of the studied DNA regions were submitted to GenBank (ITS: MH819177; GAPDH: MH822960; RPB2: MH822961; TEF-1 $\alpha$ : MH822962). BLAST searches showed 99\%-100\% identity with the existing sequences (including ex-type CBS 916.96) of Alternaria alternata. To confirm Koch's postulates, seven plants of $G$. jamesonii 'Comum' were inoculated with a spore suspension $\left(10^{5}\right.$ conidia $\left./ \mathrm{ml}\right)$ of A. alternata from a 10-day-old culture. After inoculation, the detached leaves were covered with plastic bags to maintain high relative humidity, maintained at $25{ }^{\circ} \mathrm{C}$ and monitored daily for symptom development. A set of seven non-inoculated plants was considered as control, with only distilled water applied. Five days after inoculation, leaves displayed symptoms similar to those observed in the field, while controls remained symptomless. Cultures re-isolated from inoculated leaves had the same morphological and molecular traits as the initial isolates. To our knowledge, this is the first report of A. alternata on G. jamesoni in Brazil.

\section{Compliance with ethical standards}

Conflict of interests We have no conflict of interest to declare.

Publisher's note Springer Nature remains neutral with regard to jurisdictional claims in published maps and institutional affiliations.

\section{References}

Woudenberg JHC, Groenewald JZ, Binder M, Crous PW (2013) Alternaria redefined. Stud Mycol 75:171-212

Cristiano Bellé

crbelle@gmail.com

1 Centro de Ciências Rurais, Departamento de Solos, Universidade Federal de Santa Maria, Santa Maria, Rio Grande do Sul 97105-900, Brazil

2 Centro de Ciências Rurais, Departamento de Defesa Fitossanitária, Universidade Federal de Santa Maria, Santa Maria, Rio Grande do Sul 97105-900, Brazil 